\title{
A new species of the genus Neocollyris W. Horn, 1901, subgenus Isocollyris Naviaux, 1994, from southern Vietnam (Coleoptera: Cicindelidae)
}

\author{
Новый виА рода Neocollyris W. Horn, 1901, подрод Isocollyris \\ Naviaux, 1994, из Южкного Въетнама (Coleoptera: Cicindelidae)
}

\author{
Andrey V. Matalin ${ }^{1,2}$ \\ A.B. Маталин ${ }^{1,2}$
}

\begin{abstract}
${ }^{1}$ Moscow State Pedagogical University, Education-Scientific Centre Ecology \& Biodiversity, Kibalchicha str. 6, build. 3, Moscow 129164, Russia. E-mail: andrei-matalin@yandex.ru.

${ }^{1}$ Московский педагогический государственный университет, УНЦ экологии и биоразнообразия, ул. Кибальчича д. 6, корп. 3, Москва 129164, Россия.

2 Pirogov National Research Medical University, Pediatric Faculty, Biology Department, Ostrovitianova str. 1, Moscow 117997, Russia.

2 Российский национальный исследовательский медицинский университет им. Н.И. Пирогова, педиатрический факультет, кафедра биологии, ул. Островитянова д. 1, Москва 117997, Россия.
\end{abstract}

KEY WORDS. Tiger beetles, Collyridini, new species, Lam Dong Province.

КЛЮЧЕВЫЕ СЛОВА. Жуки скакуны, Collyridini, новый вид, провинция Лам Донг.

ABSTRACT. Neocollyris (Isocollyris) sharovae sp.n. is described from Lam Dong Province, southern Vietnam. The new species is clearly distinguished from all known species of the subgenus Isocollyris Naviaux, 1994, by the entirely pale labrum, as well as the elytral colouration and maculation.

РЕЗЮМЕ. Из южновьетнамской провинции Лам Донг описан Neocollyris (Isocollyris) sharovae sp.n. Новый вид отличается от остальных видов подрода Isocollyris Naviaux, 1994 полностью светлой губой, а также окраской и рисунком надкрылий.

\section{Introduction}

The subgenus Isocollyris was established by Naviaux to initially include 19 species [Naviaux, 1994, 1995]. Over the following years, the species diversity of this subgenus has more than doubled [Naviaux, 2004, 2008, 2010; Matalin, Naviaux, 2008; Naviaux, Schüle, 2008; Dheurle, 2016, 2017] to reach 40 species [Wiesner, 2020]. Of them, 11 occur in Vietnam [Wiesner et al., 2017].

The present paper puts on record still one more, new species of Isocollyris found in southern Vietnam. Its distinctions from the related consubgeners are discussed as well.

Material and methods

The specimens used in this study are in the collections of the Zoological Institute of the Russian Academy of Sciences, St.-Petersburg, Russia (ZIN) and the collections of Charles Dheurle, Langres, France (cCD) and Jürgen Wiesner, Wolfsburg, Germany (cJW), as indicated below.

Measurements were taken as follows: TL - total body length without labrum (from the anterior margin of the clypeus to the apex of the elytra); HL - length of head (from the anterior margin of the frons to the anterior margin of the neck); HW — width of head (without eyes); TE - transverse diameter of eye; LE longitudinal diameter of eye; LL - length of labrum without apical teeth (from the anterior margin of the clypeus to the base of the apical teeth); LW - width of labrum (in the widest place); PL - length of pronotum (along the midline); PW - width of pronotum (in the widest place excluding the basal lobe); EL — length of elytra (from the base of the scutellum to the apex); EW width of the elytra (in the widest place); SW — width of shoulders (in the widest place).

Photographs of the habitus and individual structural details were taken using a Canon EOS 40D camera with a MP-E $65 \mathrm{~mm}$ macro lens. The images of the maxillary and labial palps were taken with Canon EOS 6D camera attached to a Carl Zeiss AXIO Scope.A1 microscope. All pictures were processed using Zerene Stacker software.

Taxonomy

Neocollyris (Isocollyris) sharovae Matalin, sp.n. Figs $1-8$.

TYPE MATERIAL. Holotype, + - S Vietnam, Lam Dong Province, $5 \mathrm{~km} \mathrm{~S}$ of Dung K'No, at light, 19-21.IV.2010, leg. A. Prokofiev (ZIN).

How to cite this article: Matalin A.V. 2021. A new species of the genus Neocollyris W. Horn, 1901, subgenus Isocollyris Naviaux, 1994, from southern Vietnam (Coleoptera: Cicindelidae) // Russian Entomol. J. Vol.30. No.4. P.390-392. doi: 10.15298/rusentj.30.4.02 
COMPARATIVE MATERIAL. Two paratypes, $\sigma^{\top}, q$ of $\mathrm{NeO}-$ collyris (Isocollyris) apiceflava Dheurle, 2017: Vietnam, Hue Province, Bach Ma National Park, $16^{\circ} 12^{\prime} \mathrm{N} 107^{\circ} 51^{\prime} \mathrm{E}$, alt. 400-1,200 m, 16-20.IV.2012, E. Jendek leg. (cCD, cJW).

DIAGNOSIS. Head elongate, black with violet lustre, frontal grooves convergent in anterior and posterior thirds, interocular excavation with an oval central impression; eyes slightly protruding. Labrum short and transverse, monochromous yellow, with eight submarginal setae and seven apical teeth. Palps entirely yellowish except for yellow-brown apical joints. Pronotum metallic bluish-green, glabrous, expanded in basal third, straight in lateral view. Prothorax bluishgreen, mesothorax dark with metallic green tinge, metathorax yellow. Coxae and trochanters yellow; fore- and mid-femora dark yellow, hind femora bichromous; tibiae and tarsi mostly dark yellow. Elytra long, with sloping shoulders, expanded apically, bright metallic green, with numerous, regularly distributed, rounded, blue pits; maculation consisting of a three-lobed humerobasal spot, a subquadrate middle spot, and a wide, crescent, apical spot. Insinuator (sternum $8^{\text {th }}$ ) with two sharp apical spines.

DESCRIPTION: TL, $9.4 \mathrm{~mm}$. Head elongate, HL/HW: 1.32, with thin isodiametric microsculpture, temples gradually convergent towards base (Fig. 5); black with violet lustre, anterior margin of genae with blue reflection; clypeus with two setae; frons narrow, frontal grooves deep, strongly convergent in anterior and posterior thirds, interocular excava- tion with an oval central impression and golden-green reflection in anterior half; eyes slightly protruding, LE/TE: 1.19; each supra-orbital plate with two long setae (right posterior one double); vertex in anterior third with sparsely arranged shallow wrinkles; occiput smooth (Figs 5-6). Labrum short and transverse, LW/LL: 2.4; monochromous yellow with extremely narrow light brown anterior and posterior margins; with eight long submarginal setae and seven apical teeth: with a very short central tooth and a pair of relatively large latero-apical teeth, as well as a small laterobasal tooth on both sides (Fig. 2). Mandibles dark yellow with brown apices and molars (Fig. 6). Maxillary (Fig. 3) and labial (Fig. 4) palps entirely yellowish except for yellow-brown apical joints with straight and truncate apices. Antennae relatively long, slightly projected towards base of pronotum; antennomere 3 the longest; scape yellow with a single apical seta, antennomeres 2-5 brown on dorsal face and yellow-brown on ventral face, antennomeres 6-11 entirely brown, antennomeres 7-10 finely pubescent on ventral face, antennomere 11 entirely and finely pubescent (Figs 1,6).

Pronotum relatively long, with a short collar, distinctly expanded in basal third (Fig. 5), straight in lateral view (Fig. 6); PL/PW: 2.38, PL/HL: 1.48; metallic bluish-green, glabrous with sparse, shallow, transverse wrinkles at the centre of disc; anterior and posterior sulci wide and shallow, anterior one distinctly wider; apical and, especially, basal lobe with distinct golden-green lustre, lateroventral portion of basal

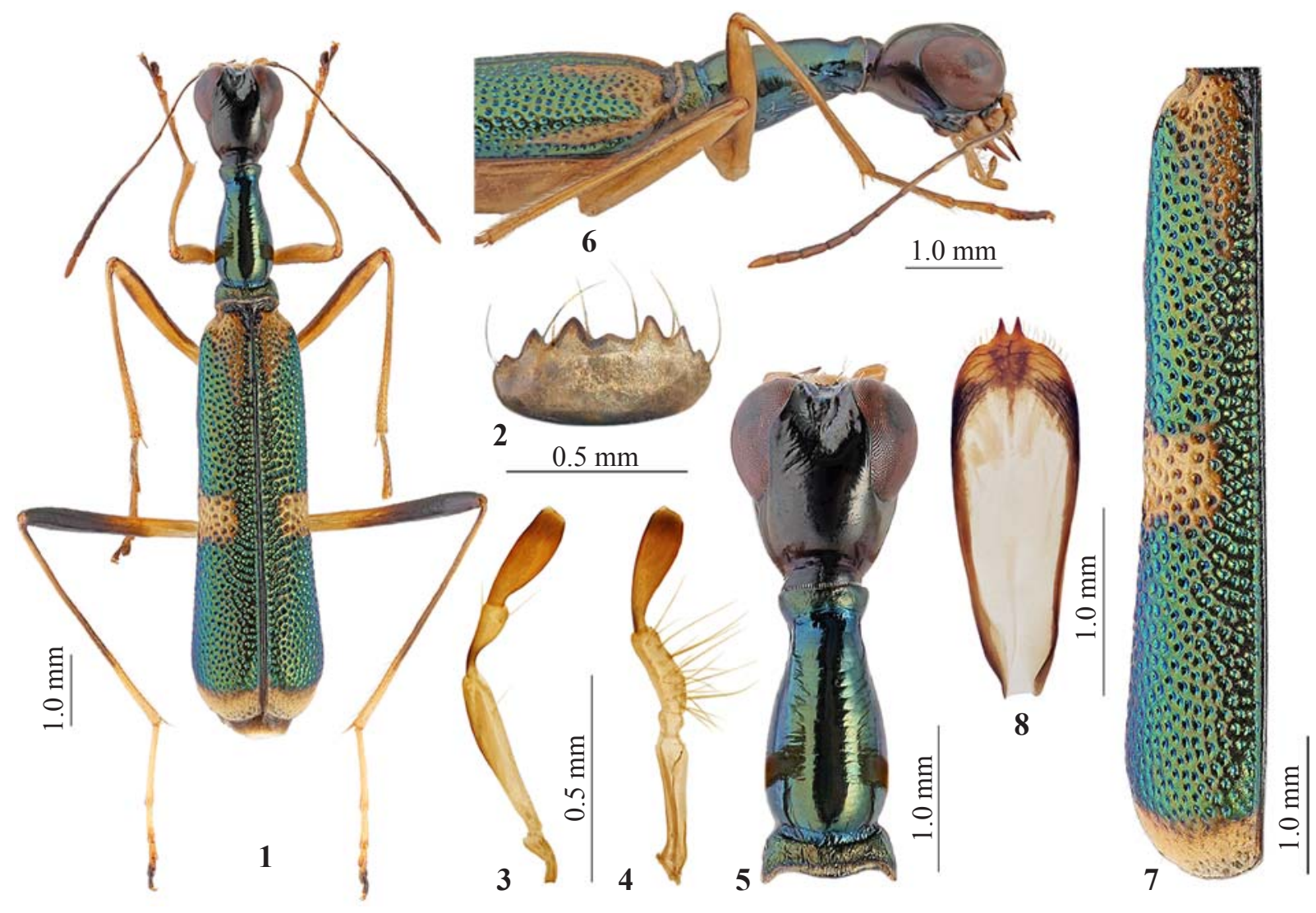

Figs 1-8. Neocollyris (Isocollyris) sharovae Matalin, sp.n., female, holotype: 1 — habitus, dorsal view; 2 - labrum; 3 - left maxillary palp; 4 - left labial palp; 5 - head and pronotum, dorsal view; 6 - head, pronotum and basal third of elytra, right lateral view; 7 - left elytron, dorsal view; 8 - insinuator (sternum $8^{\text {th }}$ ), ventral view.

Рис. 1-8. Neocollyris (Isocollyris) sharovae Matalin, sp.n., самка, голотип: 1 - внешний вид, сверху; 2 - верхняя губа; 3 - левый нижнечелюстной щупик; 4 - левый губной щупик; 5 - голова и переднеспинка, сверху; 6 - голова, переднеспинка и базальная треть надкрылий, сбоку справа; 7 - левое надкрылье, сверху; 8 - инсинуатор (стернит 8), снизу. 
lobe yellow with a group of thin, soft, sparse and white hairs. Prothorax bluish-green, pro-episternum indistinctly transversely wrinkled, prosternum sparsely pubescent with long, soft, white hairs (Fig. 6). Mesothorax dark with metallic green tinge, except for yellow supracoxal area and mesepisternum; the latter, as well as the centre of posterior margin of mesosternum with groups of sparse, soft, white hairs. Metathorax entirely yellow, metepisternum with a deep, longitudinal, central groove and very sparse, thin, white hairs in posterior third. Abdominal sternites dark brown, sternites 5 and 6 each with five thin and pale setae on each side; sternite 7 with at least 32 similar setae in anterior third and with ca. 35 yellow setae extending directly from anterior margin. All coxae and trochanters yellow; fore- and mid-femora dark yellow except for brown anterior margins, hind femora bichromous: dark-yellow in proximal half and dark brown in distal half; fore- and mid-tibiae dark yellow, indistinctly brownish at base, hind tibia yellow except for its $3 / 4$ brown inner face; tarsomeres 1-3 of fore- and mid-tarsi yellowish-brown, of hind tarsi light yellow; two apical tarsomeres of all tarsi dark brown, all claws dark yellow (Figs 1,6).

Elytra long, distinctly expanded towards apex, with sloping shoulders, EL/EW: 3.1, EL/PL: 2.95, EW/SW: 1.58; bright metallic green with light golden lustre except for light purple reflection along suture; covered with isodiametric microsculpture, with numerous relatively regularly distributed, rounded, blue pits, denser along suture and sparser at base and apex (Figs 1, 6-7); scutellum black-blue, small, with a blunt apex; suture dark, slightly protruding; epipleura brown with greenish metallic tinge. Elytral maculation consisting of three large yellow patches: a three-lobed humerobasal spot with a long juxtasutural portion, a long sublateral part (the latter extended to the level of the middle of the metepisternum), and a short central portion (Figs 1, 6-7), a large, subquadrate, middle spot (Figs 1,7) separated from lateral edge by one row of pits, and a wide crescent apical spot extending from lateral edge to suture (Figs 1, 7).

Insinuator (sternum 8) oblong-oval, sparsely pubescent with short pale setae in anterior quarter including lateral sides, with two sharp spines with apices slightly curved towards ventral side, and a short oblong ridge under notch between spines (Fig. 8).

Male unknown.

ETYMOLOGY. The new species honours my late teacher, the famous Russian entomologist, Professor Inessa Khristianovna Sharova.

COMPARISON. Neocollyris (Isocollyris) sharovae sp.n. seems to be especially close to $N$. (I.) apiceflava Dheurle, 2017 (male and female paratypes, cCD, cJW, revised), but is easily distinguished by the entirely yellow labrum (vs. bichromous in $N$. (I.) apiceflava); the frontal grooves strongly convergent in anterior and posterior thirds ( $v s$. first subparallel and then divergent in $N$. (I.) apiceflava); the bright green colouration of the pronotum and elytra ( $v s$. dark blue, cobalt-blue or bluegreen in $N$. (I.) apiceflava); the shape and size of the elytral maculae: very wide bright yellow spots in $N$. (I.) sharovae sp.n., vs. narrower dull yellow spots in $N$. (I.) apiceflava.
To accommodate the new species, the first two couplets in the key to the species of the subgenus Isocollyris from Vietnam [Wiesner et al., 2017] must be modified as follows:

1. Elytral apex with a yellow band

- Elytral apex without yellow band ................................. 2

A(1). Labrum bichromous with a pale central area; head, pronotum and elytra dark blue or blue-green; elytral spots dull yellow and relatively narrow.

N. (I.) apiceflava Dheurle, 2017

- Labrum uniformly pale; head dark violet, pronotum and elytra bright green; elytral spots bright yellow and very wide N. (I.) sharovae sp.n.

Acknowledgements. I am very grateful to Artem Prokofiev and Pavel Udovichenko (both Moscow, Russia), as well as to Charles Dheurle (Langres, France) and Jürgen Wiesner (Wolfsburg, Germany) who kindly lent material for this study. Sergei Golovatch (Moscow, Russia) kindly checked the English.

\section{References}

Dheurle Ch. 2016. Description de six espèces nouvelles du genre Neocollyris Horn, 1901 (Coleoptera, Cicindelidae) // Arvernsis. Nos75-76. P.1-14.

Dheurle Ch. 2017. Neocollyris (Isocollyris) apiceflava, nouvelle espèce du Vietnam // L'Entomologiste. T.73. No.1. P.37-39.

Matalin A.V., Naviaux R. 2008. New species of subgenus Isocollyris Naviaux, 1994 (Coleoptera: Cicindelidae: Neocollyris) from northern Vietnam // Euroasian Entomological Journal. Vol.7. No.1. P11-13.

Naviaux R. 1994. Revision du genre Collyris (sensu lato) (Col., Cicindelidae) // Bulletin mensuel de la Société linnéenne de Lyon. T.63. P.185-216.

Naviaux R. 1995. Les Collyris (Coleoptera, Cicindelidae). Revision des genres et description de nouveaux taxons. Lyon: Société linnéenne de Lyon. 332 pp.

Naviaux R. 2004. Les Collyris (Coleoptera, Cicindelidae). Complément à la «Révision du genre Collyris (sensu lato)» et description de nouveaux taxons // Bulletin mensuel de la Société linnéenne de Lyon. Vol.73. No.3. P.56-142.

Naviaux R. 2008. Nouvelle contribution à la connaissance des Collyris (s. lato) (Coleoptera, Cicindelidae) // Bulletin de la Société entomologique de France. Vol.113. No.1. P.123134.

Naviaux R. 2010. Espèces nouvelles des genres Neocollyris Horn, 1901, et Collyris Fabricius, 1801 (Coleoptera, Cicindelidae) // Bulletin de la Société entomologique de France. Vol.115. No.3. P.311-324.

Naviaux R., Schüle P. 2008. Deux nouvelles Cicindèles arboricoles (Coleoptera, Cicindelidae)//Bulletin de la Société entomologique de France. Vol.113. No.3. P.455-457.

Wiesner J. 2020. Checklist of the tiger beetles of the world. $2^{\text {nd }}$ Edition. Borsdorf: Edition Winterwork. $540 \mathrm{pp}$.

Wiesner J., Bandinelli A., Matalin A. 2017. Notes on the tiger beetles (Coleoptera: Carabidae: Cicindelinae) of Vietnam // Insecta Mundi. Vol.0589. P.1-131. 